\title{
Macro-Level Determinants of Board Effectiveness in UK and Romanian Listed Companies: A Conceptual Approach
}

\author{
Peter JANSEN ${ }^{\mathrm{a}}$, Gabriel Viorel RAITA ${ }^{\mathrm{b}}$ \\ a London School of Business and Finance \\ b "Babeş-Bolyai" University of Cluj-Napoca
}

\begin{abstract}
This descriptive and exploratory study aims to analyse and compare the macro-level determinants of board effectiveness of listed companies for two European countries, the UK and Romania. The main focus is on the relationships between national culture and legal-institutional factors (macro-determinants) and how they might affect board effectiveness in both countries. By investigating the moderating effect of macro-level determinants on board effectiveness, this research contributes to the small number of cross-border studies on board effectiveness in this area. The cross-national context of this study is also relevant against the background of the increasing internationalization of boards. This implies that the understanding of macro-determinants and their effect on board processes becomes increasingly important for boards, and especially chairs, to take into consideration.
\end{abstract}

Key terms: corporate governance, board effectiveness, UK and Romania, legal-institutional factors, financial-economic factors, national culture

JEL Classification: G34, M40

To cite this article: Peter Jansen, Gabriel Viorel Raita, Macro-Level Determinants of Board Effectiveness in UK and Romanian Listed Companies: A Conceptual Approach, CECCAR Business Review, № 10/2021, pp. 60-72, DOI: http://dx.doi.org/10.37945/ cbr.2021.10.08

\section{Introduction}

The aim of this study is to analyse and compare the macro-level determinants of board effectiveness in two European countries, the United Kingdom and Romania. The main focus is on the relationships between national culture and legal-institutional factors (macro-determinants) and how they might affect board effectiveness in both countries.

This article follows a previous study by the author (Jansen, 2021), in which the relationships between board processes, board role performance and board effectiveness were analyzed for a cross-country sample of comparable European (UK and Romania) listed companies, based on a multi-theoretic and multi-disciplinary model of board effectiveness. In line with an increasing number of studies (Basco and Voordeckers, 2015; Minichilli et al., 2012; Pugliese et al., 2015), Jansen (2021) found further evidence that board processes are stronger determinants of board effectiveness than board characteristics and confirms the relevance of the three board processes (effort norms, cognitive conflict and use of knowledge and understanding) mentioned by Forbes and Milliken (1999) in their seminal work on boards of directors as strategic decision-making groups. It also confirmed the relevance of two additional board processes, namely board communication quality and board trust (Jansen, 2021). Furthermore, Jansen (2021) used key board characteristics such as board size (Kumar and Singh, 2013), board composition (Fernández-Temprano and Tejerina-Gaite, 2019), non-executive ratio (Gill, 2013) and CEO-chair duality (Abels and Martelli, 2013) as control variables, as they can help to explain some of the board process outcomes, the main focus of his study. 
Table 1. Board characteristics in the UK and Romania

\begin{tabular}{|l|c|c|c|c|c|c|c|c|}
\hline & \multicolumn{3}{|c|}{ Romania } & \multicolumn{3}{c|}{ UK } & \multicolumn{3}{c|}{ Total } \\
\hline & Mean & Range & $\% /$ Total & Mean & Range & $\% /$ Total & Mean & $\% /$ Total \\
\hline Board size & 5.4 & $3-8$ & - & 7 & $3-12$ & - & 6.2 & - \\
\hline No. of non-executives & 4.5 & $1-7$ & $83 \%$ & 4.3 & $0-11$ & $61 \%$ & 4.4 & $72 \%$ \\
\hline CEO/Chairman ratio & 0.25 & $1-0$ & $24 \%$ & 0.07 & $1-0$ & $8 \%$ & 0.16 & $16 \%$ \\
\hline $\begin{array}{l}\text { Director } \\
\text { shareholdings (\%) }\end{array}$ & 39.7 & $0-79$ & $40 \%$ & 7.68 & $0-39$ & $8 \%$ & 23.69 & $24 \%$ \\
\hline Gender ratio & 0.96 & $0-3$ & $17.8 \%$ & 1.22 & $0-4$ & $17.4 \%$ & 1.09 & $17.6 \%$ \\
\hline Average age & 51.3 & $41-65$ & - & 58.7 & $50-67$ & - & 55 & - \\
\hline Foreigner ratio & 0.57 & $0-5$ & $10.5 \%$ & 1.48 & $0-5$ & $21 \%$ & 1.02 & $16.5 \%$ \\
\hline One/two tier boards & 1.12 & $1-2$ & $88 \%$ & 1 & $1-1$ & $100 \%$ & 1.06 & $94 \%$ \\
\hline
\end{tabular}

Source: Authors' contribution.

As shown in Table 1, board size in the UK (7) is slightly higher compared to Romania (5.4). The percentage of non-executives on the other hand is considerably higher in Romania (83\%) than in the UK (61\%), as are CEO/chairman ratio ( $24 \%$ versus $8 \%$ ) and director shareholdings ( $40 \%$ versus $8 \%$ ). Gender ratios are similar in both countries, whereas the average age of board members (59 versus 51) and the foreigner ratio are higher in the UK (21\% versus $11 \%)$ than in Romania.

Recent cross-border research into board effectiveness increasingly shows the moderating effect of different legal-institutional frameworks, financial-economic factors and work-related individual values and behaviours (macro-level determinants) on the relationship between board characteristics, board processes and board effectiveness at the micro-level (Minichilli et al., 2012; Van Essen et al., 2013; Voordeckers et al., 2014). Therefore, this study assumes a macro-level (national context) approach to board effectiveness, in which the effect of these macro-level determinants on board effectiveness is analysed and hypothesized.

Based on the above findings and considerations, the following theoretical framework for evaluating and measuring board effectiveness in a cross-national context was developed (Figure 1).

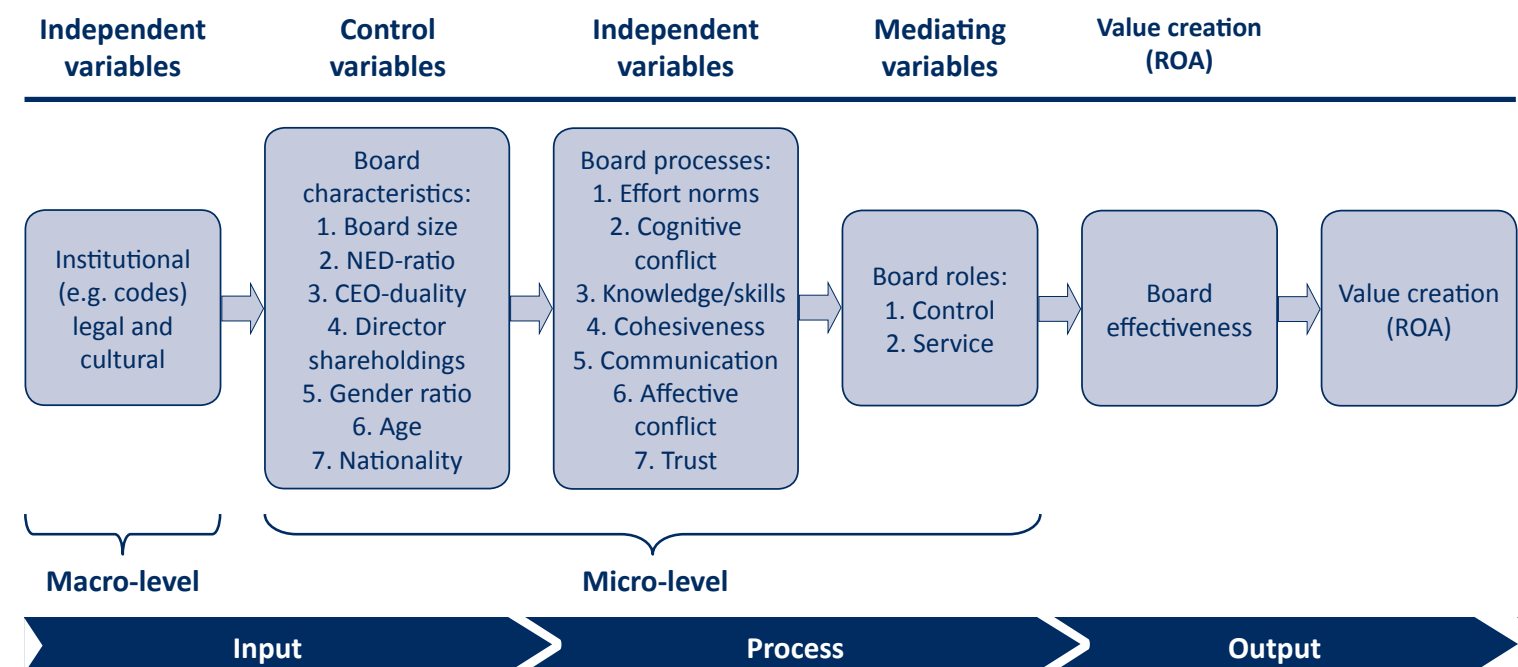

Figure 1. Theoretical construct for analyzing board effectiveness in a cross-national context

Source: Jansen (2021), derived from Farquhar (2011) and Minichilli et al. (2012). 
The focus of this study is limited to listed companies. Firstly, there are more publicly available data about listed companies due to disclosure requirements. Secondly, in most countries voluntary codes of corporate governance have become subject to capital market mechanisms and are even preconditions for stock market listing, making them quasi-mandatory (OECD, 2019), which further increases their comparability. Lastly, listed companies' behaviour often influences privately owned companies and ultimately sets a country's corporate governance standards (Aguilera and Cuervo-Cazurra, 2009).

\section{National context: The macro-level determinants of board effectiveness in the UK and Romania}

In this paper the different macro-level determinants (legal-institutional, financial-economic, national culture) that influence board effectiveness are analyzed for both countries, the UK and Romania. Van Essen et al. (2013) examined the effects of country-level corporate governance mechanisms on firm performance and found that 25 percent of the heterogeneity in firm performance is among countries, indicating the importance of including macro-level determinants. The national context of laws, regulations, voluntary codes and stock exchange listing requirements together form the foundation for corporate governance (Clarke, 2007). These institutional elements are based on the history, culture and political-economic conditions of specific nations (Frentrop, 2003). This chapter looks into the different legal-institutional frameworks and policy documents and codes related to corporate governance in both countries, their financial-economic systems and finally their different national cultures, especially work-related individual values and behaviours.

\section{- Legal frameworks in the UK and Romania}

Shleifer and Vishny (1997) were among the first to research the effect of the existing legal framework on a country's corporate governance system, in particular shareholder protection and ownership structure. La Porta et al. $(1997,1998,1999)$ researched the relationship between legal systems and corporate governance in 49 countries across the globe and found that there are basically three legal traditions. According to La Porta et al. (1997), the French origin legal system offers the weakest shareholder protection. The Romanian legal system would fall under this legal tradition. The second, the English origin legal system of common law offers the highest shareholder protection. The third legal tradition, the German and Scandinavian origin legal systems, are somewhere in between these opposite poles.

The UK Companies Act (2006) and associated legislation provide the legal framework, which regulates the operation of the company towards shareholders and their relations with each other. The Companies Act 2006, but also the Corporate Manslaughter and Corporate Homicide Act 2007 and the Bribery Act 2010 recognize that director responsibility not only extends to shareholders but to stakeholders at large and that they have a duty to pursue the long-term well-being of the company, a model of stewardship in the interest of all stakeholders (Bloomfield, 2013).

The Cadbury Report (1992) was effectively the first formalized corporate governance code in the world and has since inspired many other countries and institutions (for example, the OECD 1999 Corporate Governance Code). The UK Corporate Governance Code has advanced since it was first issued in 1992. There has been a clear change in focus from structure and processes to values and behaviour in the UK approach to corporate governance and board effectiveness. Increased focus on internal control systems and risk management, a higher level of board independency, more engagement between boards and shareholders, awareness for the relationship between remuneration policy and risk-taking, increased board diversity and finally the exemplary role of the board in setting the culture, values and ethics of the company have all contributed to its advancement (Financial Reporting Council, 2018). 
Nevertheless, the typical UK approach to corporate governance, based on a voluntary ("comply or explain") rather than a law-based framework, has remained virtually unchanged (Solomon, 2013). The code has always emphasized the importance of clarity of roles within the board, board responsibilities, accountability and transparency.

Countries with civil law systems (also known as European Continental Law) such as Romania only consider legislative ratifications or codification (rather than legal precedents, as in common law) legally binding. Corporate governance reform in these countries is usually achieved through legislative changes to a country's corporate or commercial laws (Solomon, 2013). The Romanian Company Law (No. 31/1990) sets the framework for all company forms and contains provisions regarding the management of companies, the appointment and dismissal of directors, the composition and functioning of the members of management bodies, their remuneration, responsibility and liability towards the company (Busu, 2015). The legal requirements for corporate governance are largely in place in Romania and Company Law No. 31/1990 and Capital Markets Law No. 297/2004 have been updated regularly in order to comply with the relevant EU regulations. Main governance issues remain as far as state-owned enterprises (SOE's) and state-controlled enterprises (SCE's) are concerned (EGO 109/2011 and Law No. 111/2016), especially the separation between the government's ownership and policy-making function (European Commission, 2015).

The latest Romanian Corporate Governance Code entered into force in 2016. The code promotes higher standards of governance and transparency of listed companies and is more explicit in what is required from the board (Bucharest Stock Exchange, 2019). In terms of composition, the majority of the members of the board of directors should be non-executive and at least two non-executive members of the board should be independent in the case of Premium Tier Companies.

Although both codes are voluntary ("comply or explain"), they have become subject to capital market mechanisms and are preconditions for stock market listing, making them quasi-mandatory (Braendle and Noll, 2006). Compared to the UK Corporate Governance Code, the Romanian code is still very much about board structural characteristics and conformance and less about board behaviour and performance, and despite improvements over time, the code is still more permissive than the UK Corporate Governance Code (Stanciu and Caratas, 2015).

\section{- The quality of public institutions in the UK and Romania}

Based on the above, the legal and administrative framework of corporate governance in both countries seems to indicate a medium (Romania) to strong (UK) legal environment. However, this also depends on the quality of the institutions that have to uphold and implement these laws and regulations. The role of institutions goes further than the legal framework. The approach of government institutions with respect to market freedom and efficiency are also critical: overregulation and red tape, lack of transparency, corruption, lack of quality services supporting the business sector, and political dependence of the judicial system all reduce corporate governance standards and ultimately limit competitiveness and firm performance (World Economic Forum, 2018). This seems especially relevant for Romania, which does not have the long-standing legal and institutional foundations to handle corporate governance issues (McGee and Preobragenskaya, 2004) and corporate governance is often more driven by legal conformity than an earnest attempt to improve corporate governance practices (Zattoni and Cuomo, 2008).

According to the Global Competitiveness Report (World Economic Forum, 2018), the UK scores 7.9 out of $10\left(12^{\text {th }}\right)$ in terms of quality of public institutions (Figure 2), while Romania scores a mere 5.1 out of 10 (85 $5^{\text {th }}$ place). 


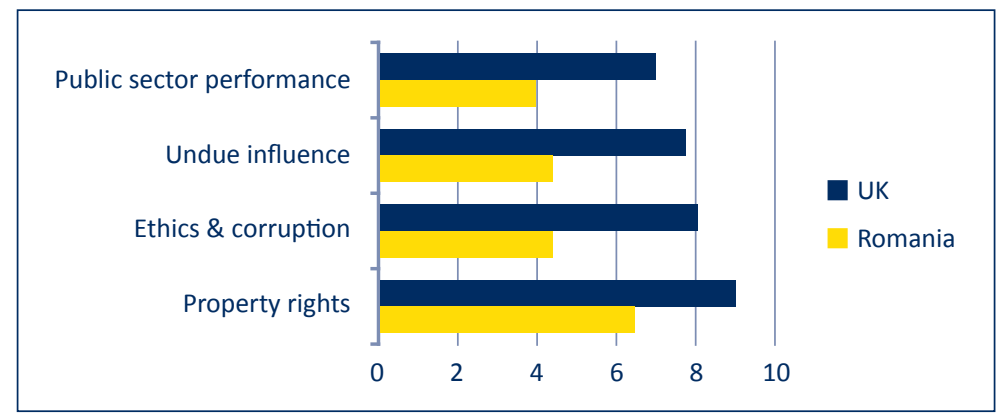

Figure 2. Quality of public institutions UK-Romania

Source: World Economic Forum (2017-2018), Global Competitiveness Index.

Differences are highest on the dimension ethics \& corruption, followed by undue influence (comprised of judicial independence and favouritism), public sector performance (which includes efficiency of legal framework and transparency of government decision-making). This shows that the quality of the Romanian public institutions responsible for the implementation and enforcement of governance-related laws and regulations is low compared to the UK, especially as far as corruption, legal efficiency and judicial independence are concerned.

\section{- Financial market development in the UK and Romania}

The last financial crisis has underlined the importance of a healthy and well-functioning financial sector. Healthy financial markets can provide capital for private sector investment via bank loans, well-regulated stock markets, venture capital and other financial instruments. Financial institutions act in a way as overseers of corporate success and play as such a key role in corporate governance systems. Consequently, banks and stock markets present a crucial part of institutional arrangements for corporate governance. They require suitable regulation to protect the rights of investors and other economic players. This presupposes vigorous bank balance sheets, healthy competition and effective financial control (World Economic Forum, 2018). According to the definition of Burrows and Low (2015), the financial system is "the sum of all the financial assets owned by banks and non-bank financial companies in the United Kingdom" (p. 115). Standing at 20 trillion pounds, it is almost twelve times bigger than the UK annual gross domestic product (GDP). The largest part of the UK financial system is formed by the banking system (Burrows and Low, 2015). The Romanian financial system's assets as a proportion of GDP stands at $82 \%$, compared to almost $1200 \%$ in the UK. The banking sector is highly dominant within the financial system, with a share of $80 \%$. Banks are mainly privately owned (92\%) and heavily dominated by foreign banks, in line with most other CEE countries (Hardi and Buti, 2012). Efficiency and competitiveness are low to medium compared to the UK, indicating relatively high banking costs, but the financial system is overall trustworthy and offers high legal protection (World Economic Forum, 2018).

As this study focuses on listed companies, the stock market is of particular interest. The London Stock Exchange (LSE) had a market capitalization of more than 4.5 trillion Euros in March 2019, turning it into the largest stock exchange in Europe and $6^{\text {th }}$ largest stock exchange in the world (London Stock Exchange, 2019). UK listed firms constitute a critical part of economic activity. In 2018 the market capitalization of UK listed companies, as a percentage of gross domestic product, was around 180\% (World Bank, 2018).

The Bucharest Stock Exchange (BSE) reopened in 1995, almost 50 years after the Communist government closed it down. The main market, where the largest companies are listed, is the Regulated Market. In 2018, 88 companies were listed on BSE's main Regulated Market, about half of them manufacturing companies. However, after taking out companies involved in insolvency procedures or who were delisted during 2017-2018 
only 73 companies remain. In 2018, the BSE had a total market capitalization of 36 billion Euros, almost insignificant compared to the LSE's 4.5 trillion Euros. Market capitalization as a proportion of GDP stood at just under $20 \%$ in 2018 , against $180 \%$ for the UK. The share in the total market capitalization of the first ten companies is $47 \%$ in Romania, indicating a highly concentrated stock market. Around $10 \%$ is held by one (foreign) company, oil \& gas company Petrom (Bucharest Stock Exchange, 2019).

According to the Global Competitiveness Report (World Economic Forum, 2018), the UK ranks $13^{\text {th }}$ out of 140 countries in terms of financial market development (Figure 3), while Romania ranks $88^{\text {th }}$.

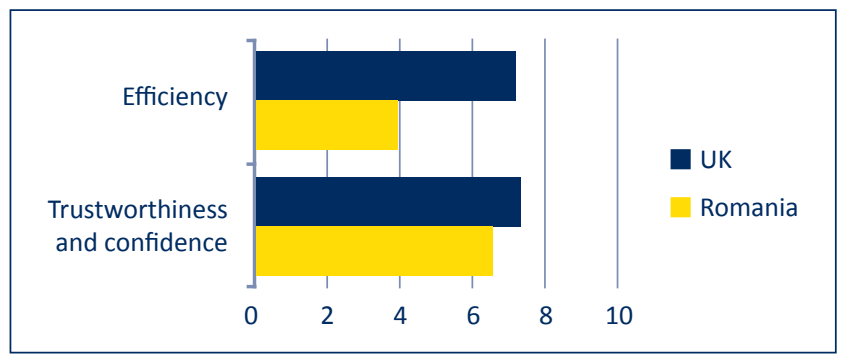

Figure 3. Financial market development UK-Romania

Source: World Economic Forum (2018), Global Competitiveness Index.

Regarding investor protection and appropriate regulation, the UK's financial market scores 7.3 out of 10 $\left(25^{\text {th }}\right)$ on the composite dimension trustworthiness and confidence, whereas the Romanian financial market scores 6.7 out of 10, ranking $42^{\text {nd }}$ in the world (World Economic Forum, 2018). This shows that the financial system in both countries is overall trustworthy and offers sound legal protection. However, within this composite dimension, Romania scores low on regulation of securities exchanges, 4.9 out of 10, compared to 8 out of 10 for the UK. Looking at the efficiency of the financial markets in both countries, the picture is rather different. This dimension is composed of variables such as availability and affordability of financial services and access to and availability of equity financing, loans and venture capital. Here the UK scores $7.2\left(14^{\text {th }}\right)$, while Romania only scores 4 out of 10 and sits in $124^{\text {th }}$ place (World Economic Forum, 2018). If also the low number of listed companies (88) in Romania is taken into consideration, it can be concluded that the Romanian stock market is not yet a competitive and efficient financial mechanism (Pohoață et al., 2016). The UK stock market on the other hand, and indeed the financial market at large, is highly competitive and offers a stable regulatory environment (World Economic Forum, 2018). As such, it constitutes a crucial part of the UK corporate governance system.

\section{- Ownership structure in the UK and Romania}

Most corporate governance research has traditionally focused on legal frameworks and ownership structure and acknowledges that both can have a substantial effect on a company's corporate governance system (La Porta et al., 1997, 1998, 1999; Shleifer and Vishny, 1997; Solomon, 2013; Zattoni and Cuomo, 2008).

The UK stock market is characterized by a broad make-up of share ownership. The largest sector is foreign investors (rest of the world) with 54\%, up from a mere $3 \%$ in 1981, underlining the increasing international character of the LSE. This category includes all types of foreign investors, from individual to institutional. The second largest category is made up of UK-based institutional investors, with almost $30 \%$ ownership. The last category are individuals with $12 \%$, a sharp decline since 1963 when individuals owned $54 \%$ of UK quoted shares in terms of total value (Office for National Statistics, 2018).

As stated before, the Romanian stock market is highly concentrated in terms of company size, with the first 10 companies covering almost 50\% of total market capitalization (Bucharest Stock Exchange, 2019). The 
BSE does not differentiate overall share capital per ownership category, but it does differentiate between dispersed shareholders and block holders, who hold at least $5 \%$ of the company's share capital and therefore have the option to significantly influence the decision-making process during the general shareholders meeting or within the board.

Corporate ownership is dominant in Romania. In 2018, approximately $80 \%$ of the existing ownership blocks (this includes foreign ownerships) belonged to corporations, while less than $20 \%$ belong to individuals. This is consistent with earlier findings. Pană (2010) also found that individual block owners were almost without exception involved in the boards of their respective companies. From a corporate governance perspective, this implies that the separation of ownership and management is effectively bridged, as the owners also control the company. Whether this leads to more or less compliance with corporate governance mechanisms and increased board effectiveness remains to be seen. Only seven listed companies have dispersed ownership with no block holders reaching the $5 \%$ threshold, all of them financial companies (Bucharest Stock Exchange, 2019).

In the case of Romania, the importance of state-controlled enterprises on the Bucharest Stock Exchange and indeed the economy is considerable. In the BET, the reference index for the Romanian capital markets which follows the evolution of the 15 most liquid companies listed on the BSE regulated market, the Romanian state controls six out of 15 companies (Bucharest Stock Exchange, 2019).

In summary, ownership in Romania is highly concentrated and as a result, separation of ownership and control is relatively low compared to UK listed companies. This combined with the many inter-corporate holdings and the strong position of the state would make the Romanian corporate governance system predominantly insider-based (Pană, 2010). On the other hand, UK ownership structure is dispersed and characterized by lower ownership concentration (Office for National Statistics, 2018). As a result, separation of ownership and control of the firm remains high, but shareholders' rights are well protected and there are several methods for shareholders to exercise control, especially in the case of large institutional investors.

\section{- National culture: Work-related values in the UK and Romania}

Several studies on cross-cultural values show significant differences between work-related individual values and behaviours due to the wider political, psychological and sociological effect of nationality (Gomez-Mejia and Wiseman, 2007; Kirkman et al., 2009; Minichilli et al., 2012). These differences not only influence certain board characteristics via habits and rules embedded in institutional environments (McNulty and Pettigrew, 1996), but can also affect board processes (Hambrick et al., 2008; Minichilli et al., 2012) and ultimately board effectiveness.

The best-known and most applied theoretical and empirical work on value development within national cultures has been developed by Geert Hofstede. Hofstede (1980) organized one of the most inclusive studies of how culture influences values in the workplace. He defines culture as "the collective programming of the mind distinguishing the members of one group or category of people from others" (p. 25). In his model of national culture, Hofstede originally distinguished four dimensions: individualism/collectivism, power distance, uncertainty avoidance and masculinity/femininity. These dimensions depict broad tendencies (or values) "to prefer certain states of affairs over others" that differentiate countries (rather than individuals) from one another (Hofstede, 1980, p. 19).

Taras et al. (2010), in their meta-analysis of 598 studies depicting more than 200,000 individuals, found that all four cultural values are equally important indicators of organizationally relevant outcomes and seem especially relevant for management and boards (managers, older, male, educated) and that cultural values are stronger indicators of emotions, attitudes, perceptions and behaviours (process-related elements) than personal traits and demographics (characteristics). When comparing cultural characteristics of the UK and Romania, using Hofstede's (1980) dimensions, the following picture emerges (Figure 4). 


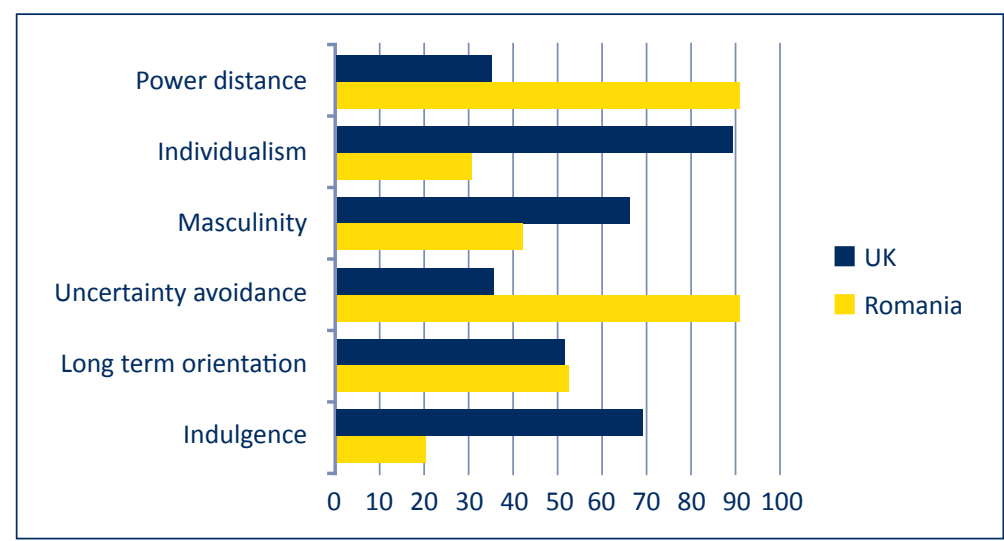

Figure 4. Cultural values in the UK and Romania

Source: Hofstede Centre (n.d.).

From the above figure it appears that both countries differ significantly ( $>$ factor 2.5 ) on the dimension's individualism, power distance, uncertainty avoidance and indulgence. This study focusses on the most opposite work-related cultural values (individualism, power distance and uncertainty avoidance) in order to assure sufficient between-country variation (Tsui et al., 2007) and be able to draw relevant conclusions about their possible moderating effect on board characteristics and processes and ultimately board effectiveness.

The first cultural value dimension, individualism-collectivism, is defined as "the degree to which people in a country prefer to act as individuals rather than as members of groups" (Hofstede, 1994, p. 6). More specifically, individualism is "a loosely knit social framework in which people are supposed to take care of themselves and of their immediate families only" (Hofstede, 1980, p. 45). The UK is with a score of 89 amongst the most individualistic countries in the world (Hofstede Insights, 2019). Romania on the other hand has a score of 30 and can be typified as a collectivistic society (Hofstede Insights, 2019). Collectivist societies are generally more focused on relationships than tasks (Sosik and Jung, 2002). Strong collectivist tendencies may stifle open and constructive debate in the board, as conflicts are avoided. This can lead to boards "rubber stamping" decisions without much debate, reducing the quality of decision-making and ultimately board effectiveness (Bankewitz, 2016; Hambrick et al., 2008).

Power distance is the second most researched cultural value (Erez, 2011). Power distance refers to "the extent to which a society accepts the fact that power in institutions and organizations is distributed unequally" (Hofstede, 1980, p. 45). This dimension copes with inequality in societies - it articulates the attitude of society with regard to these inequalities. Rather, it is the degree to which reports are not supposed to articulate discord with their superiors and superiors are not supposed to consult their reports in the decision-making process (Hofstede, 1980, 2001). Britain sits in the lower rankings of power distance with a score of 35 . In countries characterized by low levels of power distance, individual subordinates usually tend to participate in decisionmaking (Hofstede, 1984). As such, active participation tends to exceed hierarchy in decision-making (Geletkanycz, 1997). Also, conflicts are probably more encouraged than curbed (Heemskerk, 2019). Romania sits at the opposite of the spectrum with a high score (90), signifying that people accept hierarchical differences (inequalities) without further explanation (Hofstede Insights, 2019). Centralization is generally favoured, employees want to be instructed and the perfect manager is a benign dictator (Hofstede Insights, 2019). In terms of board processes, high power distance may limit open debate, as hierarchy trumps active participation (Geletkanycz, 1997).

The third dimension, uncertainty avoidance, deals with the degree to which people are scared by inconclusive or unfamiliar situations and have developed notions and institutions that try to avoid these (Hofstede Insights, 
2019). The UK scores low on uncertainty avoidance with a score of 35 . UK boards are relatively comfortable in ambiguous situations, especially when there is a fair amount of trust in the chair and/or CEO (Ye and Jermias, 2016). With a score of 90, Romania shows a very high inclination towards uncertainty avoidance. Countries who score high on this dimension usually have strict behavioural and belief codes and are biased against unconventional conduct and ideas. People's motivation is to a large extent driven by security considerations (Hofstede Centre, 2020).

Table 2. Legal-institutional, financial-economic and cultural differences between UK and Romania (scale from 1 to 10 )

\begin{tabular}{|c|c|c|}
\hline Macro indicators & UK & Romania \\
\hline Legal-institutional (mean) & 7.9 & 4.8 \\
\hline Property rights & 9.0 & 6.4 \\
\hline Ethics \& corruption & 8.0 & 4.3 \\
\hline Undue influence & 7.7 & 4.4 \\
\hline Public sector performance & 7.0 & 4.0 \\
\hline Financial-economic (mean) & 7.2 & 4.2 \\
\hline Efficiency & 7.2 & 4.0 \\
\hline Regulation of security exchanges & 8.0 & 4.9 \\
\hline Take-over market & 6.3 & 3.7 \\
\hline Cultural (high/low) & & \\
\hline Individualism & 8.9 & 3.0 \\
\hline Power distance & 3.5 & 9.0 \\
\hline Uncertainty avoidance & 3.5 & 9.0 \\
\hline
\end{tabular}

Source: Derived from World Competitive Report (2018) and Hofstede Centre (n.d.).

In line with Wan and Hoskisson (2003) and Minichilli et al. (2012), two composite measures are composed to provide evidence of the differences between the two countries. Unlike the previous authors, this study has composed one legal-institutional and one financial-economic composite, the latter stressing the importance of financial market development for corporate governance practice. A third measure - culture - has not been composed, as scores on cultural dimensions (Hofstede's work-related values) cannot be added up. Instead, the individual dimensions are shown and can be used to explain certain outcomes on board processes, board characteristics and board effectiveness.

\section{Conclusions}

The main purpose of this study was to analyze and compare the macro-level determinants of board effectiveness in two European countries, the UK and Romania. A comparable model of board effectiveness for listed companies (Jansen, 2021) was developed based on a multi-theoretic and multi-disciplinary perspective in line with increasing demands (Gaur et al., 2015; Kuoppamäki, 2018) and mostly quantifiable variables, by synthesizing recent corporate governance theories on boards of directors and board effectiveness into a new theoretical model.

The UK and Romania have very different legal, institutional and cultural contexts, and as a consequence, different governance systems. The legal and administrative framework of corporate governance in both countries seems to indicate a medium (Romania) to strong (UK) legal environment (World Economic Forum, 2018). Ownership 
(shareholder structure) is highly concentrated in Romania and separation of ownership and control relatively low, making Romanian corporate governance system predominantly insider-based (Pană, 2010). The UK ownership structure on the other hand is dispersed and characterized by low ownership concentration, resulting in a high separation of ownership and control of the firm (Toonsi, 2011). The take-over or corporate control market is another relevant external corporate governance mechanism. The UK has a dynamic takeover market compared to Romania, which is more concentrated in terms of ownership and more bank-oriented. High separation of ownership and control, combined with a dynamic take-over market and well protected shareholders' rights, qualifies the UK corporate governance system as predominantly outsider-based (Toonsi, 2011).

It is only recently that financial market development and national culture are taken into consideration when analyzing macro-determinants of board effectiveness. Financial institutions such as banks and stock markets act as overseers of corporate success and present a crucial part of institutional arrangements for corporate governance. Consequently, a healthy and well-functioning financial sector is one of the pillars of a country's corporate governance system (World Economic Forum, 2018). Although both the UK and Romanian financial sector are considered trustworthy, the Romanian stock market is not yet a competitive and efficient financial mechanism. The UK stock market on the other hand, and indeed the financial market at large, is highly competitive and offers a stable regulatory environment (World Economic Forum, 2018).

When comparing board characteristics in both countries, the emerging picture mirrors the key characteristics of the Anglo-Saxon outsider model (UK) and the mixed corporate governance model (both outsider and insider characteristics) for Romania (Toonsi, 2011). The UK model is typified by a strong external market orientation (foreigner ratio), a dispersed shareholder structure and a high separation of ownerships and control (low director shareholding) and generally a more relaxed implementation of corporate governance rules (non-executive director ratio), based on its more flexible common law system and the voluntary nature of the UK Corporate Governance Code (Solomon, 2013). Board composition in the UK sample remains very much "male (low gender ratio), pale and stale" (high average board age), as mentioned by Garratt (2005). Romania on the other hand has all the traits of the mixed corporate governance model. Although it has a market orientation, it is also oligarchic with the state and corporate block holders dominating most of the listed companies. This is somewhat reflected in the lower foreigner and gender ratios. As a result, separation of ownership and control is low (high director's shareholding), in line with Pana's findings (2010). The high non-executive ratio reflects its tendency towards conformance, which originates from its rule-based legal framework (La Porta et al., 1997) and its culture of uncertainty avoidance (Hofstede Insights, 2019). Finally, the lower age of board members reflects that Romania's market economy and corporate governance system are still relatively young.

In terms of board processes, UK boards are more likely to manifest a culture of open debate, allowing for cognitive conflicts that increase the board's ability to tap into the knowledge and skills of individual board members (Heemskerk, 2019). Discussions are channelled by a certain level of shared values, beliefs and norms, including the level of effort each individual is expected to put towards a task (Heemskerk, 2019). Board meetings are likely to be less procedural and planned, but with a clear objective, allowing for more flexibility. The prevailing leadership style generally stimulates active participation and board processes are likely to be more effective (Ye and Jermias, 2016). In Romania, strong collectivist inclinations are more likely to stifle open and constructive debate, as conflicts are generally avoided (Hofstede, 2001). This is further strengthened by the prevailing highpower distance, in which hierarchy generally trumps active participation (Hofstede Insights, 2019). Another predictor of limited open debate is the high uncertainty avoidance culture in Romania, in which conflicts and divergent opinions are generally avoided (Hofstede Insights, 2019). These tendencies can lead to boards "rubber stamping" decisions without much debate and in which conformance rather than performance is the rule, reducing the quality of decision-making and ultimately board effectiveness (Heemskerk, 2019). 


\section{References}

1. Abels, P.B., Martelli, J.T. (2013), CEO Duality: How Many Hats Are Too Many?, Corporate Governance: International Journal of Business in Society, Vol. 13, No. 2, pp. 135-147.

2. Aguilera, R.V. (2005), Corporate Governance and Director Accountability: An Institutional Comparative Perspective, British Journal of Management, Vol. 16, pp. 39-53.

3. Aguilera, R.V., Cuervo-Cazurra, A. (2009), Codes of Good Governance, Corporate Governance: An International Review, Vol. 17, No. 3, pp. 376-387.

4. Aguilera, R.V., Filatotchev, I., Gospel, H., Jackson, G. (2008), An Organizational Approach to Comparative Corporate Governance: Costs, Contingencies, and Complementarities, Organization Science, Vol. 19, No. 3, pp. 475-493.

5. Bankewitz, M. (2016), Boards' Different Advisory Tasks - What Makes Board Members Use Their Knowledge?, American Journal of Management, Vol. 16, No. 1, pp. 54-69.

6. Barrios, J.M., Bianchi, P.A., Isidro, H., Nanda, D. (2019), Boards of a Feather: Homophily in Foreign Director Appointments Around the World, BFI Working paper.

7. Basco, R., Voordeckers, W. (2015), The Relationship Between the Board of Directors and Firm Performance in Private Family Firms: A Test of the Demographic Versus Behavioural Approach, Journal of Management and Organisation, Vol. 21, No. 4, pp. 411-435.

8. Bloomfield, S. (2013), Theory and Practice of Corporate Governance. An Integrated Approach, Cambridge University Press, Cambridge.

9. Braendle, U.C., Noll, J. (2006), Enlarged EU: Enlarged Corporate Governance? Why Directives Might Be More Appropriate for Transition Economies, Corporate Governance: International Journal of Business in Society, Vol. 6, No. 3, pp. 296-304.

10. Burrows, O., Low, K. (2015), Mapping the UK Financial System, Bank of England Quarterly Bulletin 2015 Q2, pp. 114-129.

11. Busu, M. (2015), Corporate Governance Codes in Romania and European Union Countries, Review of International Comparative Management, Vol. 16, No. 1, pp. 119-128.

12. Clarke, T. (2007), International Corporate Governance. A Comparative Approach, Abingdon-on-Thames, Routledge.

13. Erez, M. (2011), Cross-Cultural and Global Issues in Organizational Psychology, in S. Zedeck (Editor), APA Handbook of Industrial and Organizational Psychology, Vol. 3, pp. 807-854.

14. Fernández-Temprano, M.A., Tejerina-Gaite, F. (2019), Types of Director, Board Diversity and Firm Performance, Corporate Governance: International Journal of Business in Society, Vol. 20, No. 2, pp. 324-342.

15. Forbes, D.P., Milliken, F.J. (1999), Cognition and Corporate Governance: Understanding Boards of Directors as Strategic Decision-Making Groups, Academy of Management Review, Vol. 24, No. 3, pp. 489-505.

16. Frentrop, P.M.L. (2003), A History of Corporate Governance 1602-2002, Deminor, Brussels.

17. Garratt, B. (2005), A Portrait of Professional Directors: UK Corporate Governance in 2015, Corporate Governance: An International Review, Vol. 13, No. 2, pp. 122-126.

18. Gaur, S., Bathula, H., Singh, D. (2015), Ownership Concentration, Board Characteristics and Firm Performance: A Contingency Framework, Management Decision, Vol. 53, No. 5, pp. 911-931.

19. Geletkanycz, M.A. (1997), The Salience of Culture's Consequences: The Effects of Cultural Values on Top Executive Commitment to the Status Quo, Strategic Management Journal, Vol. 18, No. 8, pp. 615-634.

20. Gill, S. (2013), Rethinking the Primacy of Board Efficacy for Governance: Evidence from India, Corporate Governance: International Journal of Business in Society, Vol. 13, No. 1, pp. 99-129.

21. Gomez-Mejia, L.R., Wiseman, R.M. (2007), Does Agency Theory Have Universal Relevance? A Reply to Lubatkin, Lane, Collin, and Very, Journal of Organizational Behavior, Vol. 28, No. 1, pp. 81-88.

22. Hambrick, D.C., Werder, A., Zajac, E.J. (2008), New Directions in Corporate Governance Research, Organization Science, Vol. 19, No. 3, pp. 381-385. 
23. Hardi, P., Buti, K. (2012), Corporate Governance Variables: Lessons from a Holistic Approach to Central-Eastern European Practice, Corporate Governance: International Journal of Business in Society, Vol. 12, No. 1, pp. 101-117.

24. Heemskerk, E.M., Heemskerk, K., Wats, M. (2015), Conflict in the Boardroom: A Participant Observation Study of Supervisory Board Dynamics, Journal of Management and Governance, December.

25. Heemskerk, K. (2019), Promising Avenue or Dead End Street? A Meta-Analytic Review of the Forbes and Milliken Model of Board Behaviour, Corporate Governance: International Journal of Business in Society, Vol. 19, No. 3, pp. 471-489.

26. Hofstede, G. (1980), Culture's Consequences: International Differences in Work-Related Values, Sage, Newbury Park.

27. Hofstede, G. (1983), The Cultural Relativity of Organizational Practices and Theories, Journal of International Business Studies, Vol. 14, pp. 75-89.

28. Hofstede, G. (1984), The Cultural Relativity of the Quality-of-Life Concept, Academy of Management Review, Vol. 9, No. 3, pp. 389-398.

29. Hofstede, G. (1991), Cultures and Organizations: Software of the Mind, McGraw-Hill, London.

30. Hofstede, G. (2001), Culture's Consequences: Comparing Values, Behaviours, Institutions, and Organizations Across Nations, 2nd Edition, Sage, Thousand Oaks.

31. Hofstede, G., Van Deusen, C.A., Mueller, C.B., Charles, T.A. (2002), What Goals Do Business Leaders Pursue? A Study in Fifteen Countries, Journal of International Business Studies, Vol. 33, No. 4, pp. 785-803.

32. Jansen, P.A. (2021), Board Processes Revisited: An Exploration of the Relationship Between Board Processes, Board Role Performance and Board Effectiveness in Comparable European Listed Companies, Corporate Governance: The International Journal of Business in Society.

33. Kirkman, B.L., Chen, G., Farh, J.-L., Chen, Z.X., Lowe, K.B. (2009), Individual Power Distance Orientation and Follower Reactions to Transformational Leaders: A Cross-Level, Cross-Cultural Examination, Academy of Management Journal, Vol. 52, No. 4, pp. 744-764.

34. Kumar, N., Singh, J.P. (2013), Effect of Board Size and Promoter Ownership on Firm Value: Some Empirical Findings from India, Corporate Governance: International Journal of Business in Society, Vol. 13, No. 1, pp. 88-98.

35. Kuoppamäki, M. (2018), Concepts of Board Performance: Review of Performance Metrics in Boards Research, Journal of Management and Strategy, Vol. 9, No. 3, pp. 41-53.

36. La Porta, R., Lopez-de-Silanes, F., Shleifer, A. (1999), Corporate Ownership Around the World, The Journal of Finance, Vol. 54, No. 2, pp. 471-517.

37. La Porta, R., Lopez-de-Silanes, F., Shleifer, A., Vishny, R.W. (1997), Legal Determinants of External Finance, The Journal of Finance, Vol. 52, No. 3, pp. 1131-1150.

38. La Porta, R., Lopez-de-Silanes, F., Shleifer, A., Vishny, R.W. (1998), Law and Finance, Journal of Political Economy, Vol. 106, No. 6, pp. 1113-1155.

39. McGee, R.W., Preobragenskaya, G. (2004), Corporate Governance in Transition Economies: The Theory and Practice of Corporate Governance in Eastern Europe, Working paper presented at the Global Conference on Business Economics, https://papers.ssrn.com/sol3/papers.cfm?abstract_id=538582.

40. McNulty, T., Pettigrew, A. (1996), The Contribution, Power and Influence of Part-Time Board Members, Corporate Governance: An International Review, Vol. 4, No. 3, pp. 160-179.

41. Minichilli, A., Zattoni, A., Nielsen, S., Huse, M. (2012), Board Task Performance: An Exploration of Micro- and Macro-Level Determinants of Board Effectiveness, Journal of Organizational Behavior, Vol. 33, No. 2, pp. 193-215.

42. Minichilli, A., Zattoni, A., Zona, F. (2009), Making Boards Effective: An Empirical Examination of Board Task Performance, British Journal of Management, Vol. 20, No. 1, pp. 55-74.

43. Pană, R.M. (2010), Ownership Structure in Romanian Listed Companies. A Corporate Governance and Corporate Performance Perspective, MSc thesis, Aarhus University, Aarhus.

44. Pohoață, I., Diaconaşu, D.E., Socoliuc, O.R. (2016), Economic Dynamics. Stock Market Evolution: A Relation Committed to Dysfunctionality in Romania and Croatia, Ecoforum, Vol. 5, No. 1. 
45. Pugliese, A., Nicholson, G., Bezemer, P.-J. (2015), An Observational Analysis of the Impact of Board Dynamics and Directors' Participation on Perceived Board Effectiveness, British Journal of Management, Vol. 26, No. 1, pp. 1-25.

46. Shleifer, A., Vishny, R.W. (1997), A Survey of Corporate Governance, The Journal of Finance, Vol. 52, No. 2, pp. 737-783.

47. Solomon, J. (2013), Corporate Governance and Accountability, 4th Edition, John Wiley \& Sons, New York.

48. Sosik, J.J., Jung, D.I. (2002), Work-Group Characteristics and Performance in Collectivistic and Individualistic Cultures, The Journal of Social Psychology, Vol. 142, No. 1, pp. 5-23.

49. Stanciu, V., Caratas, M. (2015), Which Is the Pulse of Romanian Corporate Governance? - An Empirical Study, Procedia Economics and Finance, Vol. 20, pp. 586-594.

50. Taras, V., Kirkman, B.L., Steel, P. (2010), Examining the Impact of Culture's Consequences: A Three Decades, Multi-Level, Meta-Analytic Review of Hofstede's Cultural Value Dimensions, Journal of Applied Psychology, Vol. 95, No. 3, pp. 405-439.

51. Toonsi, F. (2011), Cultures of Control: International Corporate Governance, PWC.

52. Tsui, A.S., Nifadkar, S.S., Ou, A.Y. (2007), Cross-National, Cross-Cultural Organizational Behavior Research: Advances, Gaps, and Recommendations, Journal of Management, Vol. 33, No. 3, pp. 426-478.

53. Van Essen, M., Engelen, P.-J., Carney, M. (2013), Does "Good" Corporate Governance Help in a Crisis? The Impact of Country-and Firm-Level Governance Mechanisms in the European Financial Crisis, Corporate Governance: An International Review, Vol. 21, No. 3, pp. 201-224.

54. Voordeckers, W., Van Gils, A., Gabrielsson, J., Politis, D., Huse, M. (2014), Board Structures and Board Behaviour: A Cross-Country Comparison of Privately Held SMEs in Belgium, the Netherlands and Norway, International Journal of Business Governance and Ethics, Vol. 9, No. 2, pp. 197-219.

55. Wan, W.P., Hoskisson, R.E. (2003), Home Country Environments, Corporate Diversification Strategies, and Firm Performance, Academy of Management Journal, Vol. 46, No. 1, pp. 27-45.

56. Ye, B., Jermias, J. (2016), The Effects of Effort and Trust on Board of Directors' Performance, Advances in Economics, Business and Management Research, Vol. 16, pp. 498-513.

57. Zattoni, A., Cuomo, F. (2008), Why Adopt Codes of Good Governance? A Comparison of Institutional and Efficiency Perspectives, Corporate Governance: An International Review, Vol. 16, No. 1, pp. 1-15.

58. Zattoni, A., Gnan, L., Huse, M. (2015), Does Family Involvement Influence Firm Performance? Exploring the Mediating Effects of Board Processes and Tasks, Journal of Management, Vol. 41, No. 4, pp. 1214-1243.

59. Bucharest Stock Exchange (2019), Trading and Statistics, http://www.bvb.ro/TradingAndStatistics/Statistics/ GeneralStatistics\#.

60. Cadbury Report (1992), Report of the Committee on the Financial Aspects of Corporate Governance: The Code of Best Practice, Gee Professional Publishing, London.

61. European Commission (2015), Country Report Romania 2015. Including an In-Depth Review on the Prevention and Correction of Macroeconomic Imbalances, European Union, Brussels.

62. Financial Reporting Council (2018), The UK Corporate Governance Code, London.

63. Hofstede Insights (2019), https://www.hofstede-insights.com/product/compare-countries/.

64. London Stock Exchange (2019), About the Main Market, http://www.londonstockexchange.com/companiesand-advisors/main-market/main/market.htm.

65. OECD (2019), OECD Corporate Governance Factbook 2019, http://www.oecd.org/daf/ca/Corporate-GovernanceFactbook.pdf.

66. Office for National Statistics (2018), Statistical Bulletin: Mergers and Acquisitions Involving UK Companies, https://www.ons.gov.uk/businessindustryandtrade/changestobusiness/mergersandacquisitions/bulletins/ mergersandacquisitionsinvolvingukcompanies/octobertodecember2018.

67. World Bank (2018), Market Capitalization of Listed Domestic Companies (\% of GDP), http://data.worldbank.org.

68. World Economic Forum (2018), Global Competitiveness Report 2018, www.weforum.org/gcr. 